\title{
Laboratory assessment of corrosion inhibitors effectiveness at oilfield pipelines of West Siberian region. III. Bubble test
}

\author{
N. N. Andreev, ${ }^{* 1}$ N. G. Anufriev ${ }^{1}$ and I. S. Sivokon ${ }^{2}$ \\ ${ }^{1}$ A. N. Frumkin Institute of Physical Chemistry and Electrochemistry, Russian Academy \\ of Sciences, Leninskii pr. 31, Moscow, 119071 Russian Federation \\ *E-mail:n.andreev@mail.ru \\ ${ }^{2}$ OJSC Transenergostroi, Derbenevskaya nab. 7, bldg. 10, Moscow, \\ 115114 Russian Federation
}

\begin{abstract}
This article continues a series of publications dedicated to lab assessment of carbon dioxide corrosion inhibitors efficiency at the oilfield pipelines of West Siberian region. Results of the bubble test are reviewed. The effect of temperature, test duration, condition of the specimen surface, the presence of a hydrocarbon phase, and concentration of inhibitors on corrosion rate and protective properties of a wide range of commercial inhibitors are analyzed. Recommendations on specific test conditions to assess the applicability of inhibitors for protection of water lines and oil pipelines with low watercut are given.
\end{abstract}

Key words: corrosion inhibitors, test methods, oilfield pipelines.

Received: January 10, 2013

doi: $\underline{10.17675 / 2305-6894-2013-2-1-017-029}$

The bubble test is a popular method for assessment of corrosion inhibitors used at oilfield pipelines [1-5]. It is characterized by low shear stresses and simulates the corrosion situation not to the full extent even at water lines and oil pipelines with low watercut where the fluid flow velocity is small [5]. However in many cases, this method can allow one to get familiar with the numerous commercial chemicals and to reject the worst efficient ones among them. The purpose of this paper is to assess the capability of this method in ranking of carbon-dioxide corrosion inhibitors for the West Siberian region and determine the test conditions that ensure the most accurate results.

We addressed these tasks using the same commercial inhibitors as in [6] as examples. The numbering of inhibitors used in that study was also kept unchanged. Inhibitors No. 3, 4 , and 7 are qualified by the manufacturers as imidazolines and No. 5 as a quaternary ammonium base. Inhibitor No. 1 is a mixture of quaternary ammonium bases and imidazoline derivatives. Inhibitors No. 2 and 6 are likely to be amines.

\section{Experimental}

During the tests, we measured the corrosion rate $(K)$ of steel electrode sensors (by the linear polarization resistance method, LPR) and flat steel specimens (by the mass loss method) placed in the test fluids through which carbon dioxide was slowly bubbled. 
The unit layout is shown in Fig. 1. It consists of a glass cell with a jacket connected to a thermostat and a pipe for $\mathrm{CO}_{2}$ supply, a magnetic stirrer that ensures circulation of the model fluid inside the cell, a gas-tight seal, an LPR sensor, and steel corrosion coupons mounted on holders.

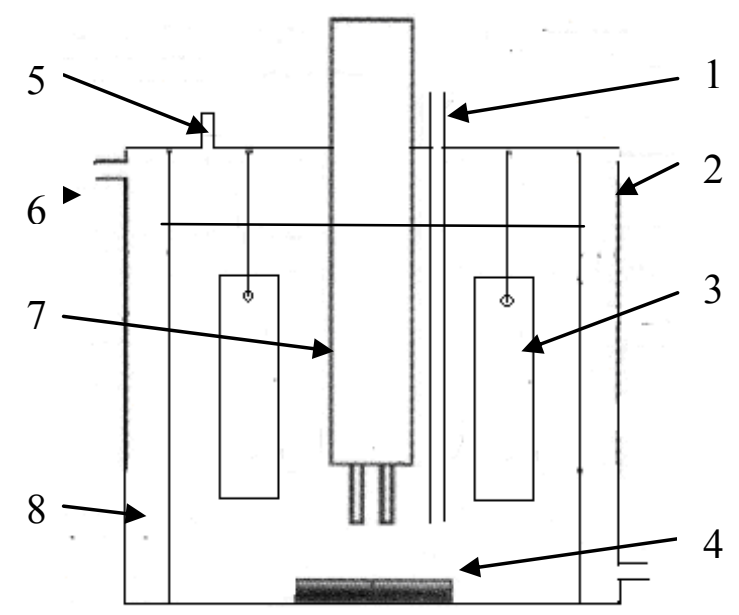

Fig. 1. Bubble test facility layout. $1-\mathrm{CO}_{2}$ supply pipe; 2 - glass cell; 3 - flat steel specimens; 4 - magnetic stirrer; 5 - nipple connected to a hydraulic seal; 6 - nipple connected to a thermostat; 7 - LPR sensor; 8 - water jacket.

A water solution simulating the formation water of the West Siberian fields and a two-phase model fluid on basis of the former were selected as the corrosive fluids. The make-up of the fluids and preparation for the test were reported previously [6].

Before the tests, the unit was disassembled. The elements contacting the test fluid were washed with a detergent and then with distilled water, rinsed with ethanol, and dried. After that, the cell was re-assembled, an LPR sensor was inserted into it, and the specimens (coupons) were mounted on the holder. The cell was then purged for 10 minutes with a stream of nitrogen to remove oxygen. The cell jacket was connected to the thermostat in order to keep the required temperature.

The simulation fluid $(0.25 \mathrm{~L})$ prepared for the tests was forced over by the nitrogen stream into the test cell. After that, the magnetic stirrer was activated at $300 \mathrm{rpm}$; fluid circulation in the jacket and $\mathrm{CO}_{2}$ bubbling started. The test time was measured from the moment the cell was filled with the simulation fluid.

Preparation of the electrode sensors and steel specimens for the tests, their post-test treatment, and calculation of $K$ values and protection levels $(Z)$ were the same as described in [6] with the only exception that the LPR sensors were not weighed. Expert-004 corrosion meters were used to monitor corrosion with LPR method.

At least three parallel experiments were made in each test fluid. Except otherwise provided in the text, the test duration was 24 hours. 


\section{Results and discussion}

The accuracy of corrosion rate estimation with the LPR method is determined by a number of factors: kinetic features of the corrosion process, conductivity of fluids, the presence of contaminants and corrosion inhibitors added, properties of the corroding materials, quality of the measuring sensors, and treatment of the electrode surface. In some cases (low conductivity of the environment, presence of inhibitors, etc.), the results of such measurements should be corrected based on gravimetric analysis or other analytical methods using correction factors. Along with the above factors, the accuracy of the corrosion rate determination by LPR is a complex function of the measured parameter values, namely, the initial difference of electrode potentials $\left(\Delta E_{\text {init }}\right)$ and the polarizing impulse $\left(\Delta E_{p o l}\right)$, the time intervals between $\Delta E_{i n i}$ measurement and $\Delta E_{p o l}$ application, as well as the time intervals between $K$ measurements, all of which are set in each case based on the test data. Herein, all measurements were carried out at $\Delta E_{p o l}=10 \mathrm{mV}$ (tree-electrode sensor), $\tau_{1}=10 \mathrm{~s}, \tau_{2}=20 \mathrm{~s}, \tau_{3}=20 \mathrm{~s}$, and $\tau_{4}=840 \mathrm{~s}$.

The effect of the measurement method on $K$ values in non-inhibited model fluids is quite clear. Almost in all tests, LPR method provided overestimated results in comparison with gravimetry (Table 1 ). The difference between the $K$ values was small in some tests but considerable in others. Thus, the $K$ values in water solution determined for activated steel specimens by gravimetrical and electrochemical methods were close. At $25^{\circ} \mathrm{C}$ they were 2.6 and $2.5 \mathrm{~g} \cdot \mathrm{m}^{-2} \cdot \mathrm{day}^{-1}$, accordingly. The measuring error increased to 0.9 and $0.3 \mathrm{~g} \cdot \mathrm{m}^{-2} \cdot$ day $^{-1}$, accordingly, at $t=8^{\circ} \mathrm{C}$. At $8^{\circ} \mathrm{C}$, the $K$ value of air-oxidized steel specimens was 3.7 according to gravimetric data and $6.4 \mathrm{~g} \cdot \mathrm{m}^{-2} \cdot$ day $^{-1}$ as per LPR data. For the same specimens at $t=25^{\circ} \mathrm{C}$, the $K$ values measured by different methods differed almost 4 -fold $\left(3.7 \mathrm{~g} \cdot \mathrm{m}^{-2} \cdot\right.$ day $^{-1}$ based on mass loss and $14.4 \mathrm{~g} \cdot \mathrm{m}^{-2} \cdot$ day $^{-1}$ based on LPR method).

Table 1. The $K$ values determined from gravimetrical data and LPR method for various test conditions.

\begin{tabular}{|c|c|c|c|c|c|}
\hline \multirow{2}{*}{ Model fluid } & \multirow{2}{*}{$\begin{array}{c}\text { Test time, } \\
\mathbf{h}\end{array}$} & \multirow{2}{*}{$t,{ }^{\circ} \mathbf{C}$} & \multirow{2}{*}{$\begin{array}{l}\text { Specimen } \\
\text { preparation }\end{array}$} & \multicolumn{2}{|c|}{$K, \mathbf{g} \cdot \mathbf{m}^{-2} \cdot \mathbf{d a y}^{-1}$} \\
\hline & & & & grav. & LPR \\
\hline Water solution & 24 & 8 & Oxidized & 3.7 & 6.4 \\
\hline Same & 24 & 25 & Same & 3.7 & 14.4 \\
\hline Same & 24 & 8 & Activated & 0.9 & 0.3 \\
\hline Same & 24 & 25 & Same & 2.6 & 2.5 \\
\hline Two-phase fluid & 24 & 25 & Oxidized & 3.1 & 4.9 \\
\hline Same & 24 & 45 & Same & 13.4 & 19.3 \\
\hline Same & 24 & 25 & Activated & 2.9 & 4.6 \\
\hline Same & 24 & 45 & Same & 13.1 & 19.3 \\
\hline
\end{tabular}




\begin{tabular}{|c|c|c|c|c|c|}
\hline \multirow{2}{*}{ Model fluid } & \multirow{2}{*}{$\begin{array}{c}\text { Test time, } \\
\mathbf{h}\end{array}$} & \multirow{2}{*}{$t,{ }^{\circ} \mathrm{C}$} & \multirow{2}{*}{$\begin{array}{c}\text { Specimen } \\
\text { preparation }\end{array}$} & \multicolumn{2}{|c|}{$K, \mathbf{g} \cdot \mathbf{m}^{-2} \cdot \mathbf{d a y}^{-1}$} \\
\hline & & & & grav. & LPR \\
\hline Water solution & 6 & 8 & Oxidized & - & 4.2 \\
\hline Same & 24 & 8 & Same & - & 6.4 \\
\hline Same & 6 & 8 & Activated & - & 0.6 \\
\hline Same & 24 & 8 & Same & - & 0.3 \\
\hline Same & 6 & 45 & Oxidized & - & 22.1 \\
\hline Same & 24 & 45 & Same & - & 19.3 \\
\hline Same & 6 & 45 & Activated & - & 18.5 \\
\hline Same & 24 & 45 & Same & - & 17.9 \\
\hline
\end{tabular}

If temperature increases, the $K$ values according to both mass loss and LPR methods over 24 hours also increase. It is only in the tests with the water solution that a $t$ increase from 8 to $25^{\circ} \mathrm{C}$ did not cause an increase in $K$ according to gravimetric data. In both sets of tests, the $K$ value for air-oxidized specimens was $3.7 \mathrm{~g} \cdot \mathrm{m}^{-2} \cdot$ day $^{-1}$ (Table 1 ).

The effect of test duration on $K$ in non-inhibited model fluids was not as apparent as in the U-cell tests [6]. According to LPR, an increase in duration of the test in the model electrolyte from 6 to $24 \mathrm{~h}$ at $t=8-45^{\circ} \mathrm{C}$ did not cause any noticeable changes in $K$ for airoxidized and activated specimens (Table 1).

Specimen activation by acid etching in the tests with the model electrolyte decreased the $K$ value. Thus, preliminary acid etching of steel at $t=8^{\circ} \mathrm{C}$ slows down the corrosion by a factor of up to 20. The reason of this phenomenon is not quite clear. Presumably, hydroxidecarbonate films of higher density with enhanced protective capacity (in comparison with airoxidized specimens) are generated on the surface of activated steel specimens in the model electrolyte. However, this fact is clearly demonstrated illustrated in Table 1.

This trend is less pronounced in a two-phase fluid. In the presence of an organic phase, $K$ almost did not depend on the treatment of steel specimens.

The effect of a hydrocarbon phase (5\% of white spirit) on $K$ in non-inhibited model fluids in this type of test is not well pronounced (Table 1). According to gravimetrical measurements at $t=25^{\circ} \mathrm{C}$, the presence of hydrocarbons caused some decrease in $K$, while according to electrochemical measurements, it reduced $K$ nearly three-fold. For activated specimens, the $K$ values almost did not change. At $t=45^{\circ} \mathrm{C}$, the $K$ values in the presence of white spirit changed only slightly according to both measurement methods.

Effect of the measurement method on inhibitor efficiency. Benchmarking demonstrated that in many tests, LPR method delivers higher values of the protective effect $(Z)$ than those determined from gravimetrical data. To illustrate this, Fig. 2 compares the $Z$ values obtained by both methods for the chemicals tested in the model water solution with air-oxidized specimens at $t=25^{\circ} \mathrm{C}$. Apparent corrosion hindrance was recorded by LPR 
method even in those cases where actual corrosion stimulation was observed (inhibitors No. 2,3 and 5 at $25 \mathrm{mg} / \mathrm{l}$ inhibitor concentration $\left.\left(C_{\text {in }}\right)\right)$.

The above trend remained unchanged under conditions simulating water lines at a lower $t$ as well (Table 2). Here, the $Z$ values for air-oxidized specimens were much lower if measured by the gravimetrical method. For the specimens activated through acid etching, the regularities of the measurement technique on the performance of the inhibitors were less clear. In some cases, the $Z$ values obtained by LPR exceeded the results acquired by the mass loss method, whereas in other cases, conversely, they were lower.

In the two-phase model fluid, the results of gravimetry and LPR were comparable.

The effect of $C_{\text {in }}$ of the protective effect. In most cases, a $C_{\text {in }}$ growth caused reduction of $K$ values (Table 2). However, in the model water solution, at $t=8^{\circ} \mathrm{C}$ inhibitor No. 3 activated the corrosion of air-oxidized steel specimens across the tested range of $C_{\text {in }}=25$ to $50 \mathrm{mg} / \mathrm{l}$. This was observed by both methods.

According to the gravimetry method, the same behavior is demonstrated by inhibitors No. 2 and 3 at $t=25^{\circ} \mathrm{C}$. These compounds stimulated the degradation of air-oxidized steel at $C_{\text {in }}=25 \mathrm{mg} / \mathrm{l}$. An increase in $C_{\text {in }}$ from 25 to $50 \mathrm{mg} / 1$ at these temperatures $t$ in the tests with air-oxidized specimens slowed down the corrosion in the model water solution. Inhibitors No. 1 and 5 were exceptions here.

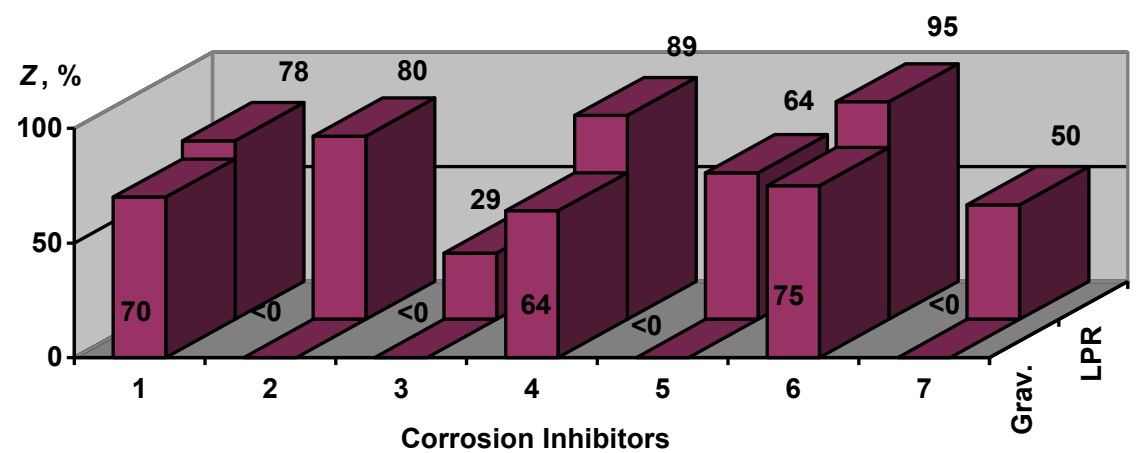

$a$

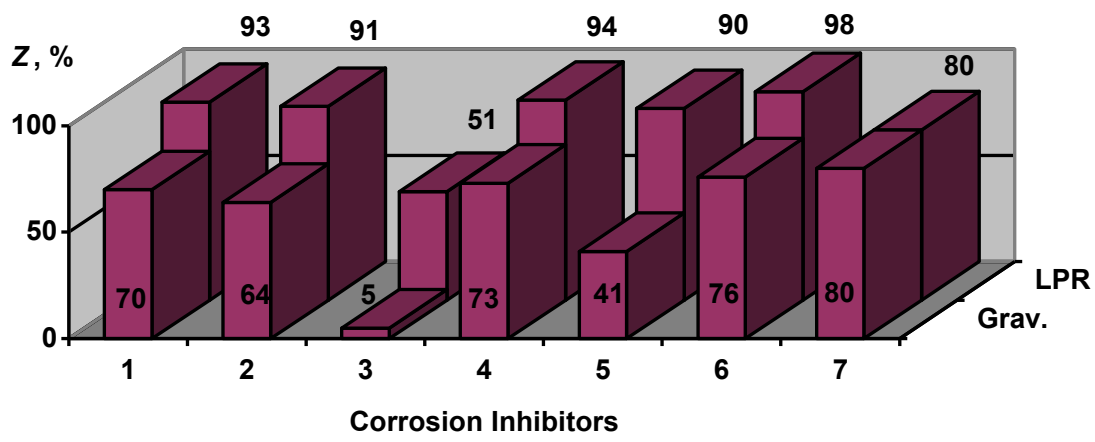

$b$

Fig. 2. $Z$ values upon addition of 25 (a) and 50 (b) $\mathrm{mg} / \mathrm{l}$ of inhibitors in model water solution at $25^{\circ} \mathrm{C}$ for air-oxidized steel specimens. 
Table 2. Protective capabilities of inhibitors estimated with gravimetrical data and LPR method for various test conditions.

\begin{tabular}{|c|c|c|c|c|c|c|}
\hline \multirow{2}{*}{$\begin{array}{l}\text { Inh. } \\
\text { no. }\end{array}$} & \multirow{2}{*}{ Model fluid } & \multirow{2}{*}{$\begin{array}{c}\mathrm{C}_{\mathrm{in}} \\
\mathrm{mg} / \mathrm{l}\end{array}$} & \multirow{2}{*}{$t,{ }^{\circ} \mathbf{C}$} & \multirow{2}{*}{$\begin{array}{c}\text { Specimen } \\
\text { preparation }\end{array}$} & \multicolumn{2}{|c|}{$Z, \%$} \\
\hline & & & & & grav. & LPR \\
\hline 1 & Water solution & 25 & 8 & Oxidized & 88 & 87 \\
\hline 1 & Same & 50 & 8 & Same & 78 & 93 \\
\hline 1 & Same & 25 & 8 & Activated & 77 & 78 \\
\hline 1 & Same & 50 & 8 & Same & 47 & 73 \\
\hline 1 & Same & 25 & 25 & Oxidized & 70 & 99 \\
\hline 1 & Same & 50 & 25 & Same & 70 & 67 \\
\hline 1 & Same & 25 & 25 & Activated & 93 & 93 \\
\hline 1 & Same & 50 & 25 & Same & 92 & 92 \\
\hline 1 & Two-phase fluid & 25 & 25 & Oxidized & 96 & 99 \\
\hline 1 & Same & 50 & 25 & Same & 98 & 98 \\
\hline 1 & Same & 25 & 25 & Activated & 99 & 99 \\
\hline 1 & Same & 50 & 25 & Same & 99 & 99 \\
\hline 1 & Same & 25 & 45 & Oxidized & 98 & 96 \\
\hline 1 & Same & 50 & 45 & Same & 96 & 95 \\
\hline 1 & Same & 25 & 45 & Activated & 98 & 99 \\
\hline 1 & Same & 50 & 45 & Same & 98 & 99,8 \\
\hline 2 & Water solution & 25 & 8 & Oxidized & 86 & 93 \\
\hline 2 & Same & 50 & 8 & Same & 93 & 98 \\
\hline 2 & Same & 25 & 25 & Same & $<0$ & 80 \\
\hline 2 & Same & 50 & 25 & Same & 64 & 91 \\
\hline 2 & Two-phase fluid & 25 & 25 & Same & 88 & 79 \\
\hline 2 & Same & 25 & 25 & Activated & 99 & 99 \\
\hline 2 & Same & 50 & 25 & Same & 99 & 99 \\
\hline 2 & Same & 25 & 45 & Oxidized & 99.8 & 96 \\
\hline 2 & Same & 50 & 45 & Same & 91 & 95 \\
\hline 2 & Same & 25 & 45 & Activated & 99 & 99 \\
\hline 2 & Same & 50 & 45 & Same & 98 & 99,8 \\
\hline 3 & Water solution & 25 & 8 & Oxidized & $<0$ & $<0$ \\
\hline 3 & Same & 50 & 8 & Same & $<0$ & $<0$ \\
\hline
\end{tabular}




\begin{tabular}{|c|c|c|c|c|c|c|}
\hline \multirow{2}{*}{$\begin{array}{l}\text { Inh. } \\
\text { no. }\end{array}$} & \multirow{2}{*}{ Model fluid } & \multirow{2}{*}{$\begin{array}{l}\mathrm{C}_{\text {in }} \\
\mathrm{mg} / \mathrm{l}\end{array}$} & \multirow{2}{*}{$t,{ }^{\circ} \mathbf{C}$} & \multirow{2}{*}{$\begin{array}{c}\text { Specimen } \\
\text { preparation }\end{array}$} & \multicolumn{2}{|c|}{$Z, \%$} \\
\hline & & & & & grav. & LPR \\
\hline 3 & Same & 25 & 25 & Same & $<0$ & 29 \\
\hline 3 & Same & 50 & 25 & Same & 5 & 51 \\
\hline 4 & Same & 25 & 8 & Same & 79 & 94 \\
\hline 4 & Same & 50 & 8 & Same & 94 & 97 \\
\hline 4 & Same & 25 & 8 & Activated & 93 & 48 \\
\hline 4 & Same & 50 & 8 & Same & 49 & 48 \\
\hline 4 & Same & 25 & 25 & Oxidized & 64 & 89 \\
\hline 4 & Same & 50 & 25 & Same & 73 & 94 \\
\hline 4 & Same & 25 & 25 & Activated & 80 & 94 \\
\hline 4 & Same & 50 & 25 & Same & 88 & 86 \\
\hline 4 & Two-phase fluid & 25 & 25 & Oxidized & 98 & 97 \\
\hline 4 & Same & 50 & 25 & Same & 95 & 98 \\
\hline 4 & Same & 25 & 25 & Activated & 99 & 99 \\
\hline 4 & Same & 50 & 25 & Same & 99 & 99 \\
\hline 4 & Same & 25 & 45 & Oxidized & 97 & 96 \\
\hline 4 & Same & 50 & 45 & Same & 96 & 99 \\
\hline 5 & Water solution & 25 & 8 & Same & 95 & 98 \\
\hline 5 & Same & 50 & 8 & Same & 99 & 99 \\
\hline 5 & Same & 25 & 25 & Same & 93 & 48 \\
\hline 5 & Same & 50 & 25 & Same & 49 & 48 \\
\hline 6 & Same & 25 & 8 & Same & 88 & 99 \\
\hline 6 & Same & 50 & 8 & Same & 88 & 99 \\
\hline 6 & Same & 25 & 8 & Activated & 87 & 87 \\
\hline 6 & Same & 50 & 8 & Same & 44 & 44 \\
\hline 6 & Same & 25 & 25 & Oxidized & 75 & 95 \\
\hline 6 & Same & 50 & 25 & Same & 76 & 98 \\
\hline 6 & Same & 25 & 25 & Activated & 91 & 89 \\
\hline 6 & Same & 50 & 25 & Same & 99 & 85 \\
\hline 6 & Two-phase fluid & 25 & 25 & Oxidized & 93 & 95 \\
\hline 6 & Same & 50 & 25 & Same & 95 & 99 \\
\hline 6 & Same & 25 & 25 & Activated & 93 & 94 \\
\hline 6 & Same & 50 & 25 & Same & 100 & 99 \\
\hline 6 & Same & 25 & 45 & Oxidized & 97 & 98 \\
\hline 6 & Same & 50 & 45 & Same & 97 & 99 \\
\hline
\end{tabular}




\begin{tabular}{ccccccc}
\hline \multirow{2}{*}{$\begin{array}{c}\text { Inh. } \\
\text { no. }\end{array}$} & Model fluid & $\begin{array}{c}\mathbf{C}_{\text {in }}, \\
\mathbf{m g} / \mathbf{l}\end{array}$ & $\boldsymbol{t},{ }^{\circ} \mathbf{C}$ & $\begin{array}{c}\text { Specimen } \\
\text { preparation }\end{array}$ & grav. & LPR \\
\hline 7 & Water solution & 25 & 8 & Same & 88 & 96 \\
7 & Same & 25 & 8 & Same & 91 & 97 \\
\hline
\end{tabular}

For activated specimens, $C_{\text {in }}$ change can result in either an increase or decrease in $Z$. In fact, according to both methods, the protective effect of inhibitor No. 1 decreased upon $C_{\text {in }}$ growth from 25 to $50 \mathrm{mg} / 1$ not only at low temperature, but also at $t=25^{\circ} \mathrm{C}$. The $Z$ values of inhibitors No. 4 and 6 also decreased with an increase in $C_{\text {in }}$ from 25 to $50 \mathrm{mg} / 1$ at $8^{\circ} \mathrm{C}$ but increased at $t=25^{\circ} \mathrm{C}$ according to gravimetrical data. According to LPR measurements, $Z$ did not increase under these conditions.

In the two-phase model fluid, significant $Z$ values (up to $99.8 \%$ ) were recorded even at $C_{\text {in }}=25 \mathrm{mg} / 1$. In this case, a further $C_{\text {in }}$ increase did not have much effect on $Z$.

The effect of temperature on $Z$ differs for water and water-organic model environments (Figs. 3, 4). In a model water solution, a temperature growth from 8 to $25^{\circ} \mathrm{C}$ reduced $Z$ for air-oxidized specimens. This is confirmed by data for inhibitors No. $1-6$ at $C_{\text {in }}=25 \mathrm{mg} / \mathrm{l}$. The data obtained for the specimens activated by acid etching demonstrate a weak effect of temperature on $Z$ values. In case of steel protection in two-phase model fluid, an increase in temperature was not accompanied by definite changes in $Z$, either.

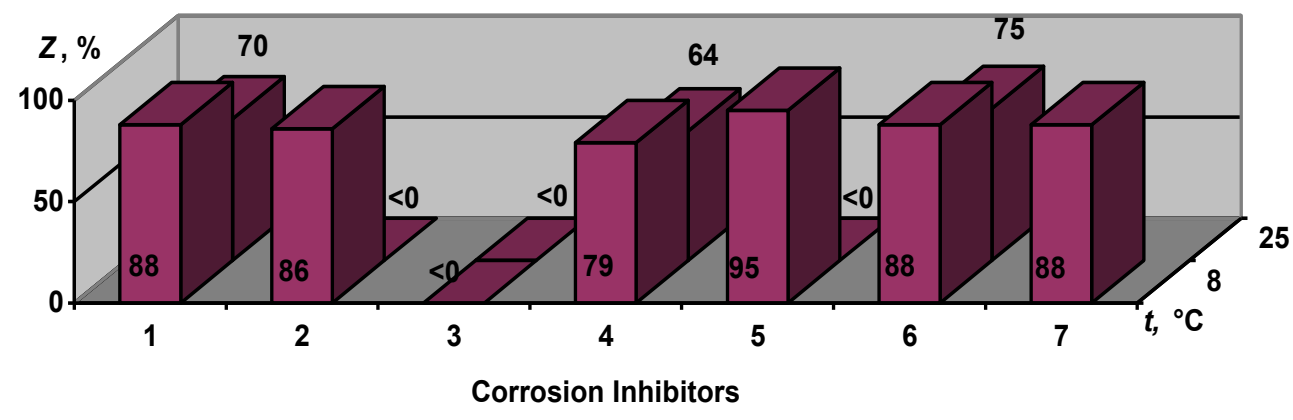

$a$

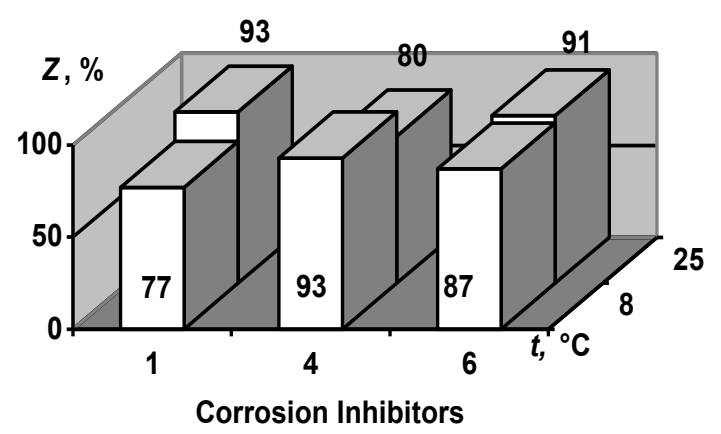

Fig. 3. Effect of temperature $(t)$ on the $Z$ of inhibitors $(25 \mathrm{mg} / \mathrm{l})$ for air-oxidized $(a)$ and activated $(b)$ specimens in model water solution as per gravimetrical data. 


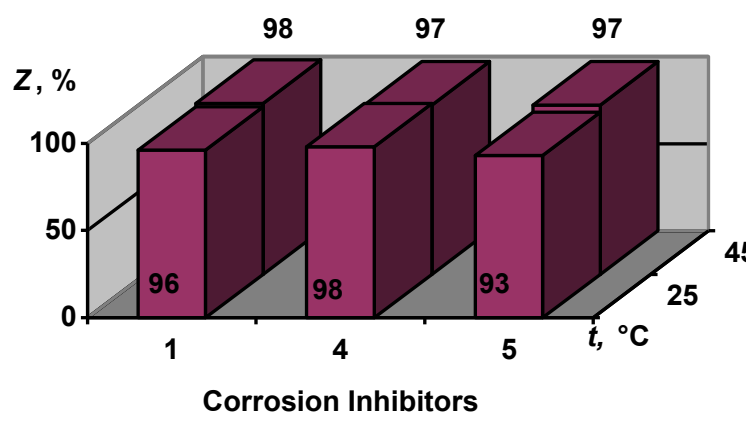

$a$

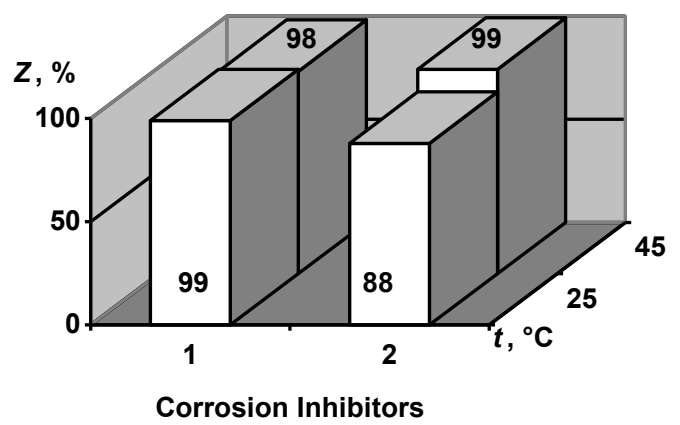

Fig. 4. Effect of temperature $(t)$ on the $Z$ of inhibitors for air-oxidized $(a)$ and activated $(b)$ specimens in two-phase model fluid as per gravimetrical data.

The effect of the test duration on $Z$ was studied at $t=25^{\circ} \mathrm{C}$ in the model water solution on air-oxidized and activated specimens at $C_{\text {in }}=25$ and $50 \mathrm{mg} / 1$ (Fig. 5). The results demonstrate that $Z$ for all inhibitors determined by LPR changes only slightly if the tests are extended from 6 to 24 hours.

The effect of specimen activation on $Z$ of inhibitors can be analyzed using the most typical examples given in Fig. 6 and 7.

The $Z$ values could slightly increase upon activation of specimens in some cases, but in most cases these changes were negligible. The most accurate conformity was observed for conditions where the $K$ values were was large (two-phase model fluid at $t=45^{\circ} \mathrm{C}$ ).

The hydrocarbon phase effect on the $Z$ of the inhibitors can be seen from comparison of the results obtained in inhibitor tests in the model solution and in two-phase fluids (Fig. 8). It demonstrates some $Z$ growth for the products upon addition of hydrocarbons to the system. The differences for air-oxidized specimens are most pronounced.

The ranking of inhibitors based on tests simulating the operation of water lines (model water solution) was made at $t=25^{\circ} \mathrm{C}$. This is because the $Z$ values decrease with an increase in temperature from $t=8$ to $25^{\circ} \mathrm{C}$, while $K$ values at least do not decrease. Thus, the protective capacity $Z$ of inhibitors at low temperature is not likely to produce a strong effect on the protection of pipelines where the failure rate is determined by the operation modes and by sections operating at elevated temperatures. The ranking was based on the most reliable gravimetrical method. The clearest differences in the performance of inhibitors were demonstrated on air-oxidized specimens. 


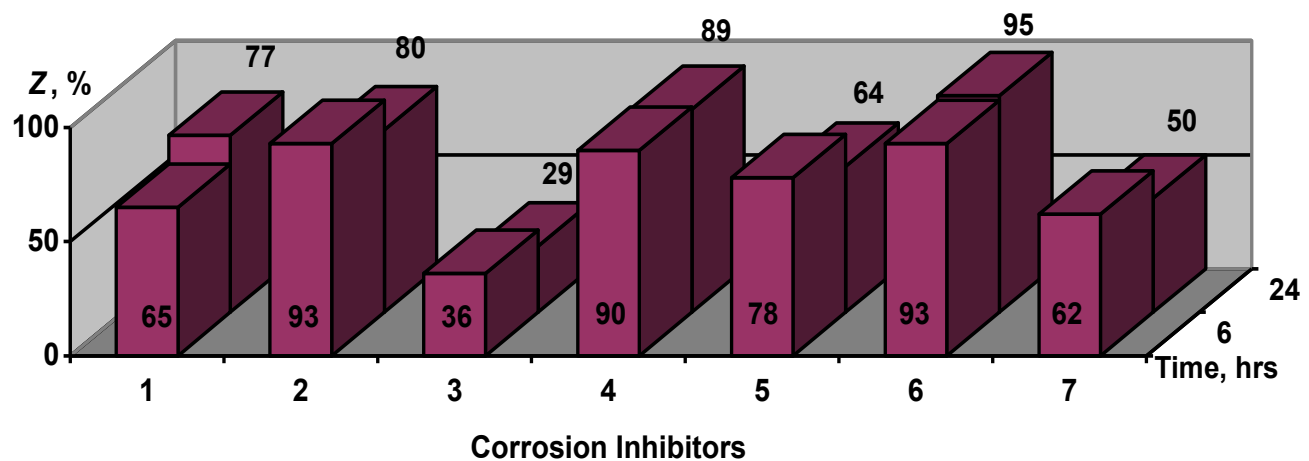

$a$

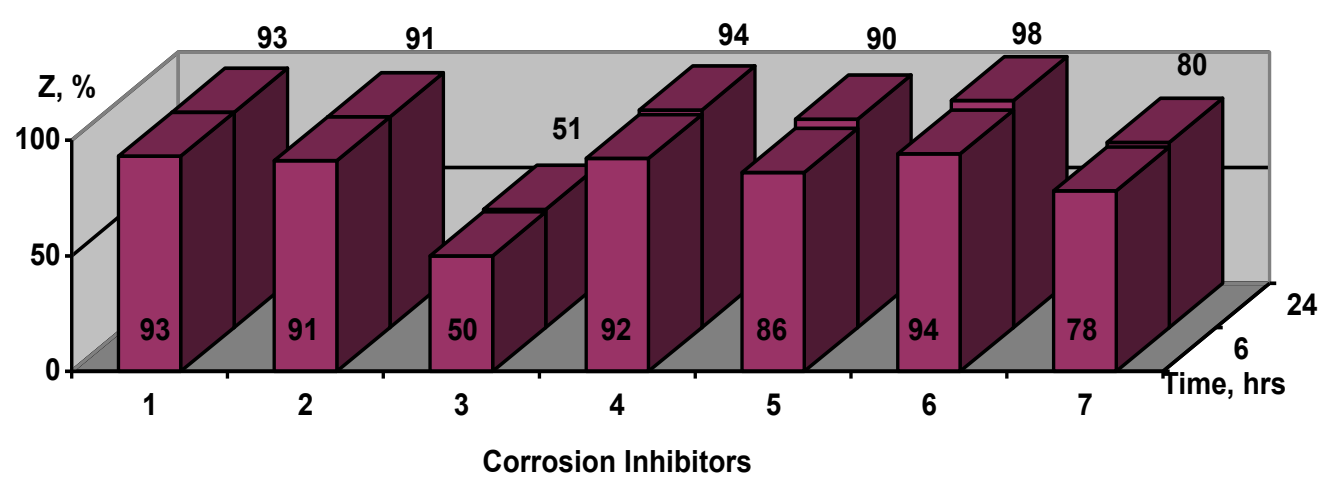

Fig. 5. Effect of test duration on the $Z$ of inhibitors $(25 \mathrm{mg} / 1-a, 50 \mathrm{mg} / \mathrm{l}-b)$ for air-oxidized specimens in model water solution at $25^{\circ} \mathrm{C}$ as measured by LPR.
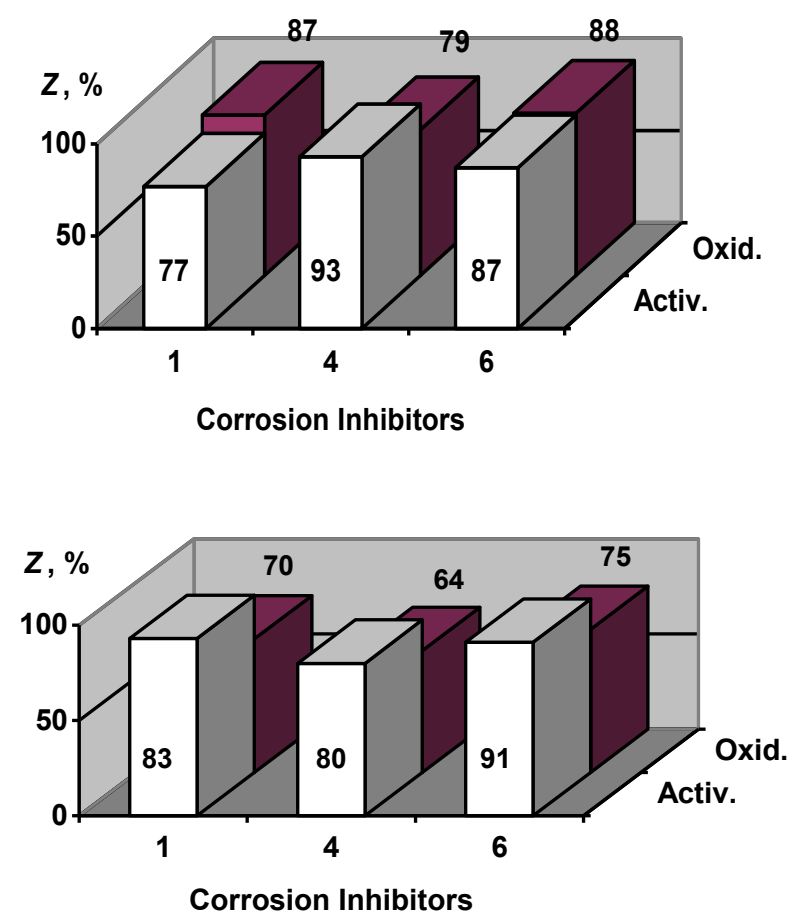

Fig. 6. Effect of steel activation on the $Z$ of inhibitors $(25 \mathrm{mg} / \mathrm{l})$ in model water solution at $8^{\circ} \mathrm{C}$ (a) and $25^{\circ} \mathrm{C}(b)$ (gravimetrical method). 


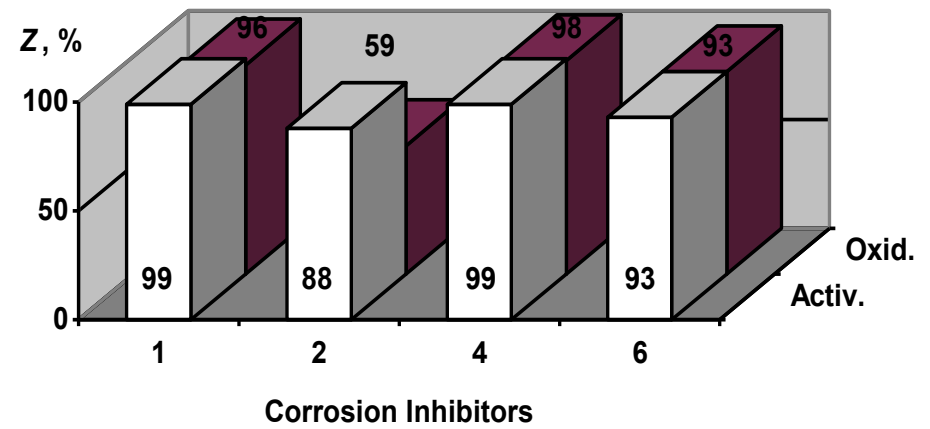

$a$

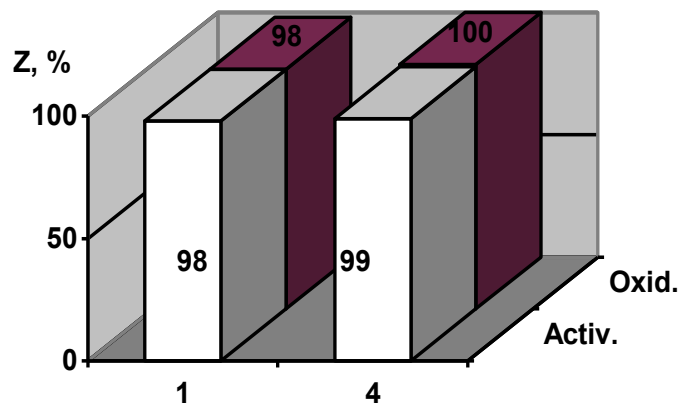

Corrosion Inhibitors

Fig. 7. Effect of steel activation on the $Z$ of inhibitors $(25 \mathrm{mg} / \mathrm{l})$ in two-phase model fluid at $25^{\circ} \mathrm{C}(a)$ and $45^{\circ} \mathrm{C}(b)$ (gravimetrical method).
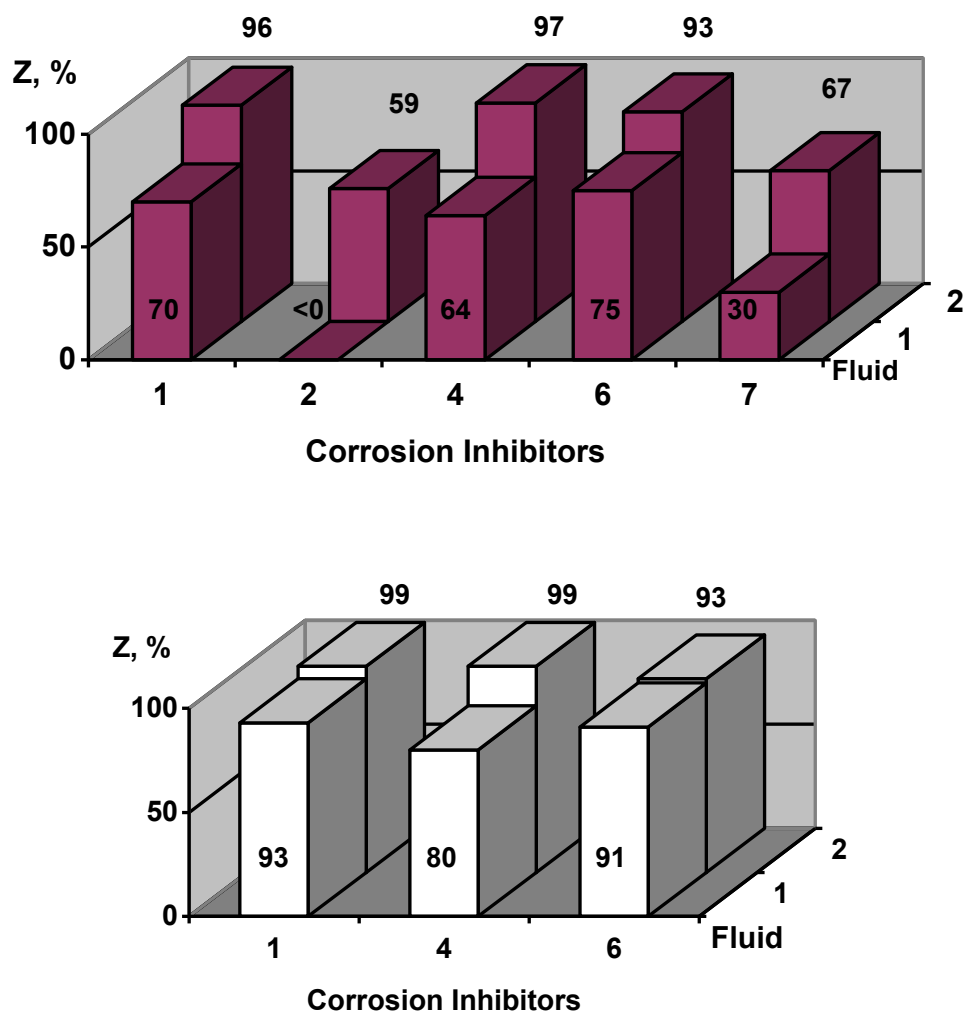

Fig. 8. Inhibitors $(50 \mathrm{mg} / \mathrm{l})$ protective effect in model water solution (fluid 1) and two-phase fluid (fluid 2) at $25^{\circ} \mathrm{C}$ for air-oxidized (a) and activated (b) specimens (gravimetrical method). 
At $C_{\text {in }}=25 \mathrm{mg} / 1$, the $Z$ of the inhibitors does not exceed $75 \%$ under these conditions. The best three inhibitors in terms of the protective capacity form the following series:

No. $6(75 \%)>$ No. $1(70 \%)>$ No. $4(64 \%)$.

The worst performance (corrosion activation) is demonstrated by inhibitors No. 2, 3, 7, and 5 (Fig. 9). At $C_{\text {in }}=50 \mathrm{mg} / 1$, the "top list" is headed by inhibitor No. 7 that stimulated corrosion at lower concentrations:

$$
\text { No. } 7(79 \%)>\text { No. } 6(76 \%)>\text { No. } 4(73 \%)
$$

None of the tested inhibitors activated corrosion under these conditions, but the worst performance was exhibited by the same inhibitors, namely, No. 2, 3, and 5.

Ranking of inhibitors based on tests simulating operation of oil pipelines with low watercut (two-phase model fluid).

Products No. 2, 3, 5, and 7 were not considered in the ranking since they can stimulate steel corrosion under certain conditions. Products No. 1, 4, and 6 demonstrated nearly the same high protective capability $(>93 \%)$ under all the model conditions.
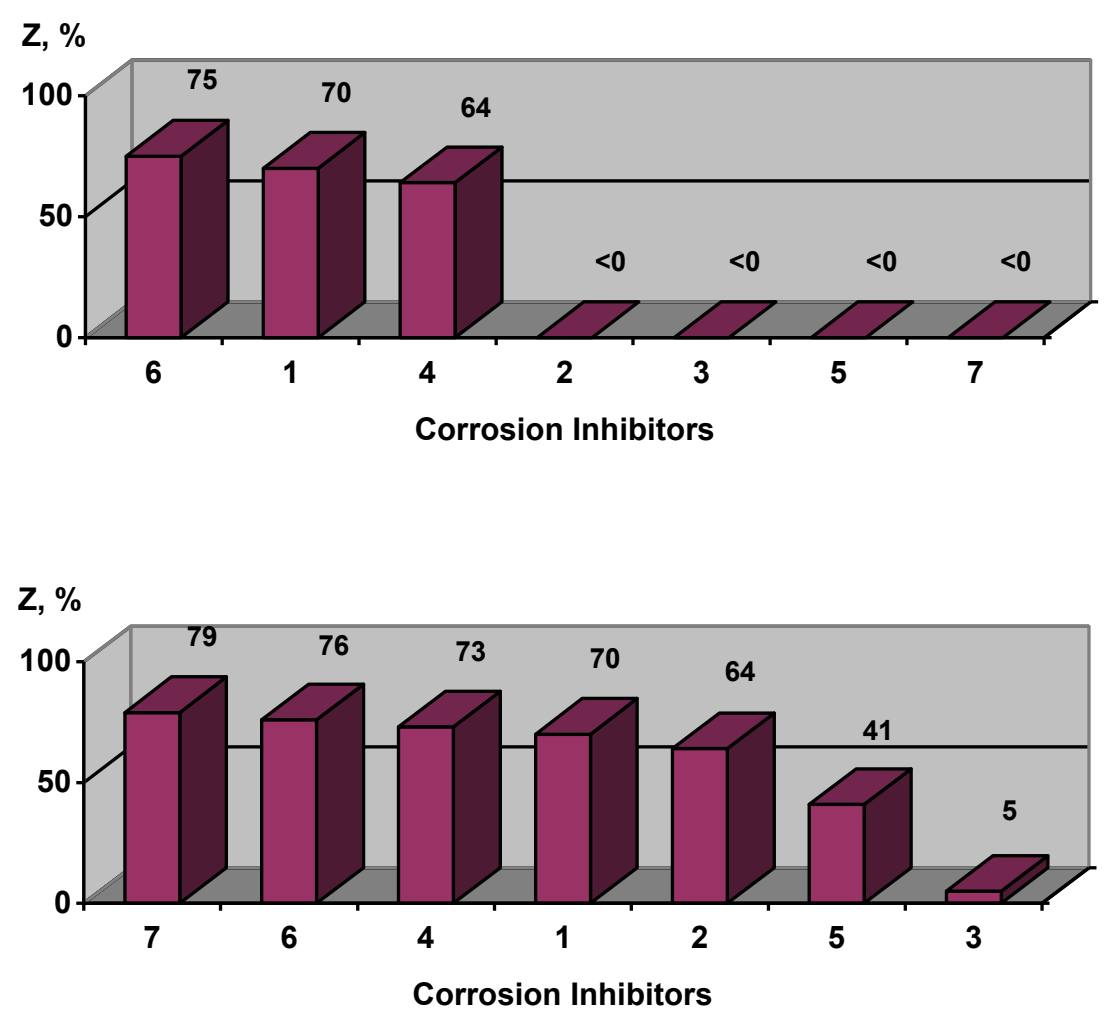

Fig. 9. Protective effects of inhibitors $(25 \mathrm{mg} / \mathrm{l}-a, 50 \mathrm{mg} / \mathrm{l}-b)$ in model water solution at $25^{\circ} \mathrm{C}$ for air-oxidized specimens. 


\section{Conclusions}

1. During the tests, one should make sure that the inhibitor to be tested is not hazardous and does not stimulate corrosion under any simulated conditions.

2 . The $Z$ values do not change much upon specimen activation. This justifies a simpler treatment of specimens that does not require acid etching.

3. The linear polarization resistance (LPR) method in the tests of this type overestimates the $K$ and $Z$ values. Lab tests of the inhibitors should be made by the more reliable mass loss method, though, considering that the LPR method is suitable for computerized monitoring of pipeline safety, it can be accepted for corrosion monitoring of the most hazardous sections.

4. The gravimetrical method is not accurate under the test conditions in 6-hour tests in inhibited solutions. The mass loss of the specimens over the test time is often smaller than the allowance of the blank test or the weighing accuracy. The duration of this type of tests should be 24 hours.

5. The bubble test is of little use for comparative testing of corrosion inhibitors for pipelines transporting a hydrocarbon phase. In this case, the test demonstrates similar high results that are not convenient for ranking of inhibitors.

6. The bubble test allows us to recommend inhibitors No.1, 4, and 6 the for protection of water lines and oil pipelines with low watercut.

7. In assessment of inhibitor protective properties, focus should be made on the highest temperature mode in the pipelines being simulated. A protective capacity of inhibitors at low temperatures do not affect the protection of pipelines.

\section{References}

1. S. Webster, A. J. McMahon, D. M. Paisley and D. Harrop, British Petroleum. Sunbury Report No. ESR.95.ER.054, November 1996.

2. M. Bartos and J. D. Watson, $9^{\text {th }}$ Europ. Symp. on Corrosion Inhibitors, Ferrara, 2000, 977.

3. J-M. Morel, W. Paulus, E. Bobillon, M. Urschey and W. Hater, http://www.bkgwater. $\mathrm{com} /$ clients/bkgwater/upload/fichiers/correlation_between_electrochemical_corrosion_t ests_and_short_time_weight_loss_tests_for_efficiency_testing_of_pdf

4. S. B. Kichenko and A. B. Kichenko, Praktika protivokorrozionnoi zashchity, 2008, 3, 20.

5. I. S. Sivokon and N. N. Andreev, Int. J. Corros. Scale Inhib., 2012, 1, 65. doi: 10.17675/2305-6894-2012-1-1-065-079

6. I. S. Sivokon, D. B. Vershok and N. N. Andreev, Int. J. Corros. Scale Inhib., 2012, 1, 130. doi: $\underline{10.17675 / 2305-6894-2012-1-2-130-145}$ 